\title{
Prevalence and associated factors with Neospora caninum infection in female water buffaloes (Bubalus bubalis) from Pernambuco, Brazil
}

\author{
Prevalência e fatores associados à infecção por Neospora caninum em fêmeas bubalinas (Bubalus bubalis) \\ em Pernambuco, Brasil
}

Pollyanne Raysa Fernandes de Oliveira ${ }^{1 *}$; Larice Bruna Ferreira Soares ${ }^{1}$; Jonas de Melo Borges ${ }^{1}$; Rinaldo Aparecido Mota ${ }^{1}$; José Wilton Pinheiro Junior ${ }^{1}$

\begin{abstract}
${ }^{1}$ Laboratório de Bacterioses dos Animais Domésticos, Departamento de Medicina Veterinária, Universidade Federal Rural de Pernambuco - UFRPE, Recife, PE, Brasil
\end{abstract}

Received April 12, 2018

Accepted August 06, 2018

\begin{abstract}
Neosporosis is one of the major parasitic diseases that causes reproductive problems, making it a limitation for optimal efficiency in livestock. The aim of the present study was to conduct a seroepidemiological survey for bubaline neosporosis and to analyse associated factors associated with $N$. caninum infection in female water buffaloes in the State of Pernambuco, northeast Brazil. The prevalence of $N$. caninum infection in the bubaline herds examined was $35.4 \%$ (122/345; 95\% CI: 30.4\%-40.7\%), at least 1 Neospora-positive animal was found in each farm. Associated factors for $N$. caninum infection identified in this study were exclusive pasture feeding (OR: 5.91, p <0.001) and purchase of animals of free fair and from reputable sellers (OR: 1.85; $\mathrm{p}=0.045$ ). In this survey, we document the occurrence of neosporosis in female water buffaloes. Associated factors should be controlled in order to reduce the risk of $N$. caninum infection in these herds.
\end{abstract}

Keywords: IFAT, neosporosis, seroepidemiology.

\section{Resumo}

A neosporose é uma das principais doenças parasitárias que causa problemas reprodutivos, torna-se possível limitar para a máxima eficiência na pecuária. Objetivou-se com este estudo realizar um inquérito soroepidemiológico e analisar os fatores associados à infecção por $N$. caninum em fêmeas bubalinas no estado de Pernambuco, Brasil. Observou-se uma prevalência de 35,4\% (122/345; IC 95\%: 30,4\%-40,7\%) para infecção por $N$. caninum e 100\% das propriedades possuíam ao menos um animal positivo. Os fatores associados à infecção por $N$. caninum neste estudo foram alimentação exclusiva a pasto (OR: 5,91; $\mathrm{p}<0,001)$ e aquisiçấo de animais de feiras livres e criadores conhecidos (OR: 1,85; $\mathrm{p}=0,045)$. Registra-se a ocorrência da infecçáo por $N$. caninum em fêmeas bubalinas e os fatores associados que precisam ser corrigidos para reduzir o risco de infecção nesses rebanhos.

Palavras-chave: RIFI, neosporose, soroepidemiológico.

\section{Introduction}

Water buffaloes (Bubalus bubalis) are rustic animals that are able to thrive in remote, difficult-to-access areas. Despite the tolerance of bubalines to difficult conditions and their resistance to a number of pathogens, they are still susceptible to some infectious and non-infectious diseases (ADLAKHA \& SHARMA, 1992). The producer should therefore meet certain sanitary requirements in order to achieve higher reproductive rates, ensuring herd health,

${ }^{*}$ Corresponding author: Pollyanne Raysa Fernandes de Oliveira. Departamento de Medicina Veterinária, Universidade Federal Rural de Pernambuco - UFRPE, Rua Dom Manoel de Medeiros, s/n, Dois Irmãos, CEP 52171-900, Recife, PE, Brasil. e-mail: pollyanne_raysa@hotmail.com and preventing the spread of pathogens, including the protozoan parasite Neospora caninum (CHRYSSAFIDIS et al., 2011). In buffaloes, this coccidium is one of the infectious agents that can impact animal productivity (CHRYSSAFIDIS et al., 2011), leading to reproductive losses such as abortions and recurrent estrus (CHRYSSAFIDIS et al., 2015).

In Brazil, buffaloes are bred for milk and beef, with a population of 1,970,941 million (IBGE, 2016). The northern part of the country accounts for the largest share of the Brazilian buffalo herd with 904,813 thousand head, followed by the Southeast, Northeast, South and Central-West regions. The third largest 
buffalo herd is in Northeast, with 10,437 thousand heads located in the state of Pernambuco (IBGE, 2016).

Many serological surveys on $N$. caninum infection in water buffaloes have been carried out by researchers in different parts of the world with prevalences ranging from 1.50 to $88.30 \%$ (BRASIL et al., 2015; CAMPERO et al., 2007; CHRYSSAFIDIS et al., 2015; DUBEY et al., 1998; FUJII et al., 2001; FERROGLIO et al., 2003; GALVÃO et al., 2013; GONDIM et al., 2007; GUARINO et al., 2000; GENNARI et al., 2005; HUONG et al., 1998; HAMIDINEJAT et al., 2015; KONNAI et al., 2008; KONRAD et al., 2013; MEENAKSHI et al., 2007; MOORE et al., 2014; NASIR et al., 2011; NEVERAUSKAS et al., 2015; PORTELLA et al., 2016; RODRIGUES et al., 2005; ROMERO-SALAS et al., 2017; SOUZA et al., 2001; SENGUPTA et al., 2012; SILVA et al., 2010, 2014, 2017; VOGEL et al., 2006; YU et al., 2007).

However, few studies have reported the associated factors for $N$. caninum infection in buffaloes. According to studies carried out by Moore et al. (2014) and Nasir et al. (2011), the age of the water buffaloes and the presence of dogs in the premises are considered to be associated factors for the occurrence of neosporosis, respectively. $N$. caninum infection in the water buffalo species may be clinically silent and epidemiological studies should be carried out on a regular basis in order to characterize the dynamics of infection and identify associated factors for the occurrence of the disease. Such studies would help in the future to minimize production losses associated with neosporosis in bubaline herds (CHRYSSAFIDIS et al., 2015).

Considering the scarcity of data and economic losses related to neosporosis in water buffaloes, the aim of the present study was to conduct a seroepidemiological survey for $N$. caninum infection in buffaloes and identify associated factors with positive serology in female water buffaloes in the State of Pernambuco, northeast Brazil.

\section{Materials and Methods}

\section{Study area}

Farms included in the survey were located in the counties of the Agreste and Zona da Mata mesoregion in the State of Pernambuco, northeast Brazil, where the largest water buffalo herds are found according to data provided by the Agriculture Defense of State of Pernambuco (ADAGRO).

\section{Sampling}

A cross-sectional study was carried out using a convenience, non-probability sampling technique. The sample size required for this seroepidemiological survey was estimated considering a bubaline population of 10,437 heads (IBGE, 2016) and an expected prevalence for $N$. caninum infection of $19.1 \%$ (BRASIL et al., 2015). Based on this data, a minimum sample size of 238 buffaloes was deemed necessary, considering a 95\% confidence interval and statistical error of 5\% (THRUSFIELD, 2004).

A total of 345 blood samples from of female water buffaloes in reproductive age, from different herds in the following counties of the State of Pernambuco were collected: Água Preta city $(\mathrm{n}=90)$;
Canhotinho city: $(\mathrm{n}=21)$; Maraial city $(\mathrm{n}=23)$; Rio Formoso city $(\mathrm{n}=48)$, and Ribeirão city $(\mathrm{n}=163)$ (Figure 1$)$. Total of 10 properties were sampled based on availability, by non-probability sampling, considering the number of females in reproductive age in each premise, using the aforementioned parameters.

\section{Sample collection}

Blood samples were collected without anticoagulant from the lateral coccygeal veins by venipuncture. Disposable needles (40 X $12 \mathrm{~mm}$ ) with Vacutainer tubes were used. Each sample was identified and transported to the Laboratory in isothermal boxes. Serum was obtained from each blood sample after centrifugation at $300 \mathrm{rpm}$ for 10 minutes and stored in labeled polypropylene microtubes at $-20^{\circ} \mathrm{C}$ until the serological test was performed.

\section{Serology}

Search for anti- $N$. caninum antibodies on serum samples of water buffaloes was performed using the Indirect Fluorescence Antibody Test (IFAT) (DUBEY et al., 1998), using slides pre-sensitized with the $\mathrm{NcSp} 7$ strain, with fluorescein isothiocyanate-labeled anti-IgG bovine (Sigma, St. Louis, USA) (KENGRADOMKIJ et al., 2015). A cut-off value with the IFAT at 1:100 dilution was used (PORTELLA et al., 2016). IFAT slides were examined by fluorescence microscopy using an epifluorescence microscope (Olympus Bx 51, Olympus Inc., Tokyo, Japan) at 400x magnification. Samples were regarded positive when $N$. caninum tachyzoites exhibited complete peripheral fluorescence. Previously tested positive and negative buffalo serum samples were included in every slide as controls.

\section{Associated factors with Neospora caninum infection}

Associated factors were assessed using structured questionnaires, which included the following objective questions: production system (dairy, beef, dairy and beef); breeding system (intensive; semi-intensive; extensive); type of breeding system (open herd, closed herd); feeding system (grass, forage/creep feeding); consortium creation (yes; no); animal purchasing (independent seller, fairs/ independent seller); quarantine animals (yes; no); presence of wildlife in the farm (yes; no) and presence of dogs in the farm (yes; no).

\section{Data analysis}

To identify factors associated with $N$. caninum infection, a univariate analysis of the variables of interest was performed using the Pearson's chi-squared test or Fisher's exact test, when deemed appropriate. Subsequently, a logistic regression was performed considering the serological status of the animal (positive or negative) as the dependent variable. The independent or explanatory variables considered in the final model were those that presented statistical significance $<0.05$. This probability was stipulated to prevent that possible factors associated with $N$. caninum, were excluded from 


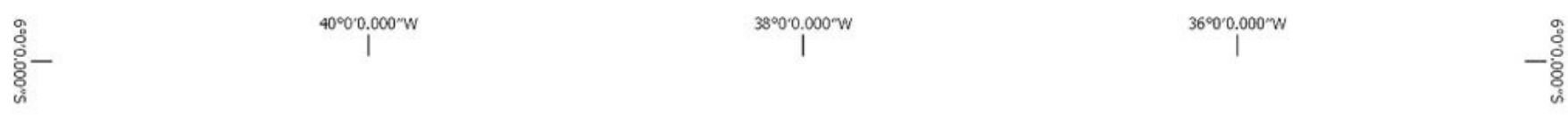
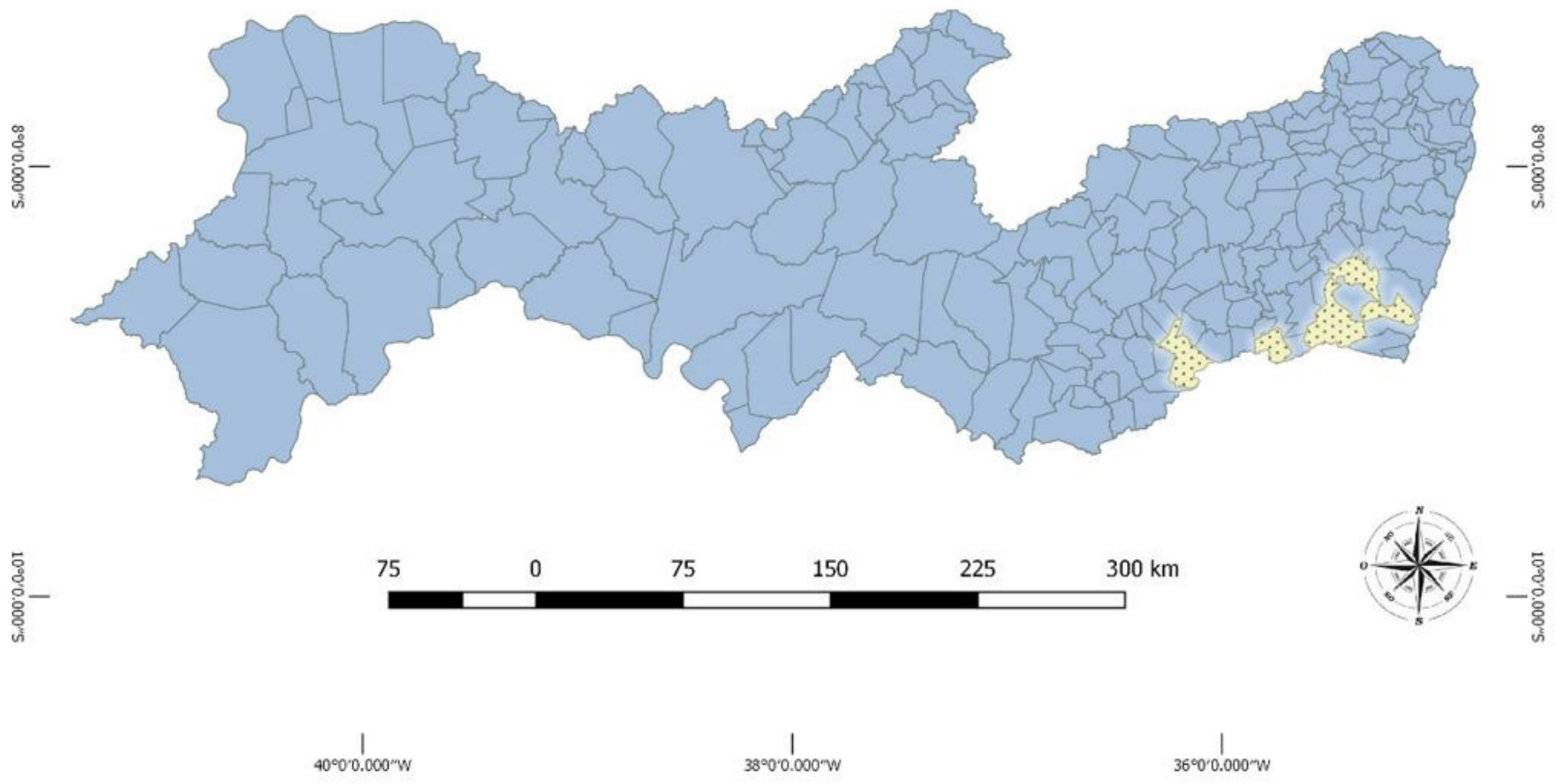

Figure 1. Distribution map of the municipalities sampled, located in the state of Pernambuco, Brazil.

the analysis. The Epi-Info ${ }^{\mathrm{Tm}} 7.0$ software was used to perform the statistical calculations (HOSMER \& LEMESHOW, 1989).

\section{Research ethics}

The research proposal was approved by the Committee on Animal Research and Ethics of the University (license no 104/2016).

\section{Results}

In the present study, the prevalence of $N$. caninum in female water buffaloes was $35.4 \%$ (122/345, C.I. $30.4 \%-40.7 \%)$. There was at least one Neospora-positive animal in each farm. Prevalences of $N$. caninum infection in the bubaline herds examined ranged from $7.0 \%$ to $47.61 \%$. The prevalence of anti-N. caninum antibodies by municipality is shown in table 1 . When evaluating the occurrence of abortion, it was present in only one of the evaluated herds (1/10).

Associated factors with the positive serology for $N$. caninum infection in the female water bufallos studied are shown in Table 2. Associated factors with the positive serology for $N$. caninum
Table 1. Anti-Neospora caninum antibody prevalence in female water buffaloes from the Agreste and Zona da Mata mesoregion of the State of Pernambuco, northeast Brazil.

\begin{tabular}{lccccccc}
\hline \multicolumn{5}{c}{ City } & \multicolumn{5}{c}{ IFAT } & & \\
\cline { 2 - 3 } & A.F. & R.F.\% & & A.F. & R.F.\% & \multirow{2}{*}{ Total } \\
\hline Água Preta & 39 & 43.3 & & 51 & 56.7 & 90 \\
Canhotinho & 9 & 42.9 & & 12 & 57.1 & 21 \\
Maraial & 4 & 17.4 & & 19 & 82.6 & 23 \\
Ribeirão & 49 & 30.1 & & 114 & 69.9 & 163 \\
Rio Formoso & 21 & 43.7 & & 27 & 56.3 & 48 \\
\hline
\end{tabular}

Acronyms: IFAT - Indirect Fluorescence Antibody Test; A. F. - absolute frequency; R. F. - relative frequency.

infection identified in the present study were: (1) water buffaloes' grazing (OR: 5.91, 95\% CI: 2.60-13.39), and (2) animals of free fair and/or from reputable sellers (OR: 1.85, 95\% CI: 1.01-3.39). In the present study, domestic dogs were present in $60 \%(6 / 10)$ of the bubaline farms studied. In the present study, domestic dogs were present in $60 \%(6 / 10)$ of the bubaline farms studied with seropositive buffaloes. The presence of domestic dogs 
Table 2. Assessed factors associated with the positive serology for N. caninum infection in bubaline farms from the Agreste and Zona da Mata mesoregion of the State of Pernambuco, northeast Brazil.

\begin{tabular}{|c|c|c|c|c|c|c|}
\hline \multirow{2}{*}{ Variable } & \multirow{2}{*}{$\mathbf{N}$} & \multirow{2}{*}{$\begin{array}{c}\text { IFAT } \\
\text { Positive (\%) }\end{array}$} & \multirow{2}{*}{ p value } & \multicolumn{3}{|c|}{ Logistic regression } \\
\hline & & & & OR & CI 95\% & p value \\
\hline \multicolumn{7}{|l|}{ Production system } \\
\hline Dairy & 124 & $46(37.1 \%)$ & $<0.001$ & 0.79 & {$[0.48 ; 1.30]$} & 0.372 \\
\hline Beef & 181 & $61(33.7 \%)$ & & 2.12 & {$[0.92 ; 4.86]$} & 0.074 \\
\hline Mixed (dairy/beef) & 40 & $15(37.5 \%)$ & & & & \\
\hline \multicolumn{7}{|l|}{ Breeding system } \\
\hline Intensive & - & - & $<0.000$ & & & \\
\hline Semi-intensive & 155 & $38(24.5 \%)$ & & 1.48 & & \\
\hline Extensive & 190 & $84(44.2 \%)$ & & & {$[0.88 ; 2.49]$} & 0.138 \\
\hline \multicolumn{7}{|l|}{ Type of breeding system } \\
\hline Open herd & 252 & $95(37.7 \%)$ & 0.084 & 0.67 & {$[0.40 ; 1.13]$} & 0.136 \\
\hline Closed herd & 93 & $27(29.0 \%)$ & & & & \\
\hline \multicolumn{7}{|l|}{ Feeding system } \\
\hline Grass & 279 & $115(41.2 \%)$ & $<0.001$ & 4.50 & {$[1.83 ; 11.03]$} & 0.001 \\
\hline Forage/Creep feeding & 66 & $7(10.6 \%)$ & & & & \\
\hline \multicolumn{7}{|l|}{ Breeding partnership } \\
\hline Yes & 44 & $20(45.5 \%)$ & 0.092 & 0.61 & {$[0.32 ; 1.16]$} & 0.136 \\
\hline No & 301 & $102(33.9 \%)$ & & & & \\
\hline \multicolumn{7}{|l|}{ Animal purchasing } \\
\hline From reputable sellers & 295 & $98(33.2 \%)$ & & 1.85 & {$[1.01 ; 3.39]$} & 0.045 \\
\hline $\begin{array}{l}\text { Animals of free fair } \\
\text { and from reputable sellers }\end{array}$ & 50 & $24(48.0 \%)$ & & & & \\
\hline \multicolumn{7}{|l|}{ Quarantine animals } \\
\hline Yes & 23 & $11(47.8 \%)$ & 0.143 & 0.57 & {$[0.24 ; 1.34]$} & 0.200 \\
\hline No & 322 & $111(34.5 \%)$ & & & & \\
\hline \multicolumn{7}{|l|}{$\begin{array}{l}\text { Presence of wildlife in the } \\
\text { farm }\end{array}$} \\
\hline Yes & 231 & $86(37.2 \%)$ & 0.180 & 0.77 & {$[0.48 ; 1.25]$} & 0.302 \\
\hline No & 114 & $36(31.6 \%)$ & & & & \\
\hline \multicolumn{7}{|l|}{ Farm dogs } \\
\hline Yes & 141 & $50(35.5 \%)$ & 0.532 & & & \\
\hline No & 204 & $72(35.3 \%)$ & & & & \\
\hline
\end{tabular}

Acronyms: N - total number of samples analyzed; IFAT - Indirect Fluorescence Antibody Test; OR - odds ratio; CI - confidence Interval.

was not deemed an associated factor with positive serology for $N$. caninum infection.

\section{Discussion}

To the authors' knowledge, this is the first study reporting the occurrence of $N$. caninum infection in female water buffaloes in the State of Pernambuco, Northeastern Brazil. In Brazil, the prevalence of $N$. caninum infection in water buffaloes varies from $14.6 \%$ to $88.0 \%$ (FUJII et al., 2001; SOUZA et al., 2001; GENNARI et al., 2005; RODRIGUES et al., 2005; VOGEL et al., 2006; GONDIM et al., 2007; SILVA et al., 2010, 2014, 2017; GALVÃO et al., 2013; BRASIL et al., 2015; CHRYSSAFIDIS et al., 2015; PORTELLA et al., 2016). Comparing results across seroepidemiogical surveys carried out by different researchers is particularly challenging, as the methodology applied, including sampling and diagnostic tests can vary between studies, especially concerning IFAT cut-off values.
Environmental and climatic factors may also influence the prevalence of infectious and parasitic diseases in farm animals in different regions of the country (NASIR et al., 2011; KENGRADOMKIJ et al., 2015). Gondim et al. (2007) mentioned that seroepidemiological surveys for antibodies to $N$. caninum carried out in different parts of the world may vary according to the diagnostic assay used and geographic area where animals are raised.

In the present study, $N$. caninum infection was detected in all bubaline herds examined, with at least one animal from each farm was positive for $N$. caninum. From an epidemiological standpoint, these results raise concern over management practices and show wide dissemination of this protozoal disease throughout the Bubaline herds of the State of Pernambuco, Brazil. Some factors may have favored the high number of positive animals in each herd including intra-herd and inter-herd infection, geographic location and environmental contamination. 
Intra-herd infection by $N$. caninum has been confirmed in water buffaloes by PCR. N. caninum DNA was detected in samples from aborted fetuses of naturally infected females (AURIEMMA et al., 2014; CHRYSSAFIDIS et al., 2011). Other studies have demonstrated that vertical (transplacental) transmission can occur in bubalines when pregnant females are infected with a high infection dose of a highly pathogenic strain (isolate) and with a low pathogenic strains of $N$. caninum (KONRAD et al., 2012; CHRYSSAFIDIS et al., 2014). Rodrigues et al. (2005) showed that the serum of female water buffaloes had detectable levels of anti- $N$. caninum antibodies for 12 months. The authors considered the possibility of maternal transfer of antibodies via milk in these animals that remained seropositive for prolonged periods.

There is limited data available in the veterinary literature regarding endogenous and exogenous transplacental infection in water buffaloes and the occurrence of persistently infected animals (REICHEL et al., 2015) and this warrants further research. In cattle, vertical (transplacental) transmission is the main route by which $N$. caninum is disseminated between animals. Infected animals are fundamental for the transmission and maintenance of $N$. caninum within seropositive herds (GOODSWEN et al., 2013).

Considering the inter-herd transmission factor, it was noted that the studied herds were composed of animals purchased from reputable breeders, and that the purchases and sales of animals were performed without knowing the $N$. caninum serological status of each of these individuals. Buying cattle from reputable breeders without knowing their sanitary status allows the movement of infected animals and the perpetuation of $N$. caninum epidemiological cycle (WILLIAMS \& WINDEN, 2014). Asmare et al. (2013) and Beck et al. (2010) demonstrated that animals purchased without any sanitary records had a higher associated with $N$. caninum infection.

In the present study, domestic dogs were present in $60 \%(6 / 10)$ of the bubaline farms studied. In the epidemiological chain of $N$. caninum, these animals are considered the definitive hosts of the protozoan parasite and oocysts are shed in canine feces, which contaminate the environment (DUBEY \& SCHARES, 2011). A study carried out on water buffaloes by researchers in Pakistan showed that there is a significant association between the presence of dogs in the farms and the prevalence of $N$. caninum infection in the premises ( $\mathrm{p}<0.05$ ) (NASIR et al., 2011). According to these authors, farm dogs contaminate the feed of water bufalloes resulting in increased prevalence of this protozoal infection. Our findings are corroborated by the results published by Nasir et al. (2011).

In our survey, water buffaloes' grazing was identified an associated factor for the occurrence of neosporosis and in 100\% of the properties the source of water was rivers and/or stream. This finding reinforces the hypothesis of contamination of the environment by $N$. caninum oocysts which are shed in the feces of dogs and of transmission of the disease by the fecal-oral route. Horizontal (postnatal) transmission of $N$. caninum in water buffaloes occurs through ingestion of food or water contaminated with oocysts of the parasite (fecal-oral transmission) (REICHEL et al., 2015). The higher prevalence of $N$. caninum infection in older animals is due to the fact that these individuals are exposed over long periods of time to an environment contaminated witn oocysts of the protozoal organism (CAMPERO et al., 2007; MOORE et al., 2014).

Wetlands inhabited by water buffaloes are an adequate environment for the survival of $N$. caninum oocysts (KENGRADOMKIJ et al., 2015). In order to assess the viability of $N$. caninum oocysts, Alves et al. (2011) confirmed the resistance of the infective form of $N$. caninum in the environment, from the evaluation of the viability of the oocyst under chemical and physical treatments.

The present study was carried out in water buffalo herds located in sugarcane producing areas and in the Agreste zone near the Atlantic Forest in Brazil. The environmental conditions in these sites favor survival and widespread dissemination of $N$. caninum oocysts. Bubalines stay submerged in large water collections many hours a day, which may favor $N$. caninum infection through ingestion of water contaminated with occysts of the parasite (ABLAS et al., 2007).

In the present survey, only one water buffalo herd had history of abortion. In a study on bubaline neosporosis that was carried out by Gondim et al. (2007), the role of $N$. caninum as a possible cause of abortion was investigated. The presence of the protozoal infection in these animals was not associated with the occurrence of abortions as no abortions were reported in the water bufallo herds studied.

$N$. caninum can cause abortions in the water buffalo. However, the occurrence of abortions in cases of bubaline neosporosis may depend on the infecting dose (CHRYSSAFIDIS et al., 2015). Sporadic abortions may go unnoticed in farms that are not under strict sanitary programmes. This partly explain the lack of reports of abortions (AURIEMMA et al., 2014; CHRYSSAFIDIS et al., 2015; KONRAD et al., 2012). Another factor that may contribute to the lack of information on reproductive parameters in cases of bubaline neosporosis is the seasonal estrous activity of female water buffaloes (CHRYSSAFIDIS et al., 2015).

We highlight the importance of assessing the serological status for $N$. caninum and the epidemiological indicators in bubaline herds, in order to determine the economic impact of this disease in water buffaloes from Brazil. Based on the results of the present study, we suggest that more research is needed on the association between $N$. caninum and pregnancy loss and other fertility problems in female water buffaloes. The $N$. caninum strains circulating in Brazilian bubaline herds should be isolated and identified for evaluation of their pathogenicity and virulence. Environmental samples should be tested for the presence of oocysts and the role of persistently infected animals in the transmission of the disease should be further investigated.

\section{Conclusion}

This study documents the occurrence of $N$. caninum infection in female water buffaloes in Pernambuco, Brazil. Associated factors with the positive serology for $N$. caninum infection should be controlled or eliminated in order to reduce the prevalence of $N$. caninum infection in these herds. Associated factors with the positive serology for $N$. caninum should be identified before a control plan is put into action. 


\section{References}

Ablas DS, Titto EAL, Pereira AMF, Titto CG, Leme TMC. Comportamento de bubalinos a pasto frente a disponibilidade de sombra e água para imersão. Cienc Anim Bras 2007; 8(2): 167-175.

Adlakha SC, Sharma SN. Infectious diseases. In: Tulloh NM, Holmes JHG. Buffalo production. Amsterdam: Elsevier; 1992. p. 271-297.

Alves AF No, Bandini LA, Nishi SM, Soares RM, Driemeier D, Antoniassi $\mathrm{NAB}$, et al. Viability of sporulated oocysts of Neospora caninum after exposure to different physical and chemical treatments. J Parasitol 2011; 97(1): 135-139. http://dx.doi.org/10.1645/GE-2571.1. PMid:21348620.

Asmare K, Regassa F, Robertson LJ, Skjerve E. Seroprevalence of Neospora caninum and associated risk factors in intensive or semi-intensively managed dairy and breeding cattle of Ethiopia. Vet Parasitol 2013; 193(1-3): $85-$ 94. http://dx.doi.org/10.1016/j.vetpar.2012.11.025. PMid:23261087.

Auriemma C, Lucibelli M, Borriello G, Carlo E, Martucciello A, Schiavo $\mathrm{L}$, et al. PCR detection of Neospora caninum in water buffalo foetal tissues. Acta Parasitol 2014; 59(1): 1-4. http://dx.doi.org/10.2478/s11686-0140201-y. PMid:24570043.

Beck R, Marinculić A, Mihaljević Ž, Benić M, Martinković F. Seroprevalence and potential risk factors of Neospora caninum infection in dairy cattle in Croatia. Vet Arh 2010; 80(2): 163-171.

Brasil AWL, Parentoni RN, Feitosa TF, Bezerra CS, Vilela VLR, Pena HFJ, et al. Risk factors for Toxoplasma gondii and Neospora caninum seropositivity in buffaloes in Paraiba state, Brazil. Rev Bras Parasitol Vet 2015; 24(4): 459-463. http://dx.doi.org/10.1590/S1984-29612015066. PMid:26689181.

Campero CM, Perez A, Moore DP, Crudeli G, Benitez D, Draghi M, et al. Occurrence of antibodies against Neospora caninum in water buffaloes (Bubalus bubalis) on four ranches in Corrientes province, Argentina. Vet Parasitol 2007; 150(1-2): 155-158. http://dx.doi.org/10.1016/j. vetpar.2007.09.002. PMid:17950535.

Chryssafidis AL, Cantón G, Chianini F, Innes EA, Madureira EH, Gennari SM. Pathogenicity of Nc-Bahia and Nc-1 strains of Neospora caninum in experimentally infected cows and buffaloes in early pregnancy. Parasitol Res 2014; 113(4): 1521-1528. http://dx.doi.org/10.1007/s00436-0143796-x. PMid:24562816.

Chryssafidis AL, Cantón G, Chianini F, Innes EA, Madureira EH, Soares RM, et al. Abortion and foetal lesions induced by Neospora caninum in experimentally infected water buffalos (Bubalus bubalis). Parasitol Res 2015; 114(1): 193-199. http://dx.doi.org/10.1007/s00436-014-4178-0. PMid:25324135.

Chryssafidis AL, Soares RM, Rodrigues AA, Carvalho NA, Gennari SM. Evidence of congenital transmission of Neospora caninum in naturally infected water buffalo (Bubalus bubalis) fetus from Brazil. Parasitol Res 2011; 108(3): 741-743. http://dx.doi.org/10.1007/s00436-010-2214-2. PMid:21181191.

Dubey JP, Romand S, Hilali M, Kwok OC, Thulliez P. Seroprevalence of antibodies to Neospora caninum and Toxoplasma gondii in water buffaloes (Bubalus bubalis) from Egypt. Int J Parasitol 1998; 28(3): 527-529. http://dx.doi.org/10.1016/S0020-7519(97)00190-2. PMid:9559371.

Dubey JP, Schares G. Neosporosis in animals: The last five years. Vet Parasitol 2011; 180(1-2): 90-108. http://dx.doi.org/10.1016/j. vetpar.2011.05.031. PMid:21704458.

Ferroglio E, Wambwa E, Castiello M, Trisciuoglio A, Prouteau A, Pradere E, et al. Antibodies to Neospora caninum in wild animals from Kenya, East
Africa. Vet Parasitol 2003; 118(1-2): 43-49. http://dx.doi.org/10.1016/j. vetpar.2003.09.006. PMid:14651874.

Fujii TU, Kasai N, Nishi SM, Dubey JP, Gennari SM. Seroprevalence of Neospora caninum in female water buffaloes (Bubalus bubalis) from the southeastern region of Brazil. Vet Parasitol 2001; 99(4): 331-334. http://dx.doi.org/10.1016/S0304-4017(01)00474-5. PMid:11511420.

Galvão GS, Flausino W, Lopes CWG. Anticorpos Anti-Neospora caninum em rebanhos de búfalos (Bubalus bubalis) no estado do Rio de Janeiro, Brasil. Rev Bras Med Vet 2013; 35(S2): 13-16.

Gennari SM, Rodrigues AA, Viana RB, Cardoso EC. Occurrence of anti-Neospora caninum antibodies in water buffaloes (Bubalus bubalis) from the Northern region of Brazil. Vet Parasitol 2005; 134(1-2): 169171. http://dx.doi.org/10.1016/j.vetpar.2005.05.064. PMid:16051440.

Gondim LFP, Pinheiro AM, Almeida MAO. Frequência de anticorpos anti-Neospora caninum em búfalos (Bubalus bubalis) criados no Estado da Bahia. Rev Bras Saúde Prod Anim 2007; 8(2): 92-96.

Goodswen SJ, Kennedy PJ, Ellis JT. A review of the infection, genetics, and evolution of Neospora caninum: From the past to the present. Infect Genet Evol2013; 13: 133-150. http://dx.doi.org/10.1016/j.meegid.2012.08.012. PMid:22985682.

Guarino A, Fusco G, Savini G, Di Francesco G, Cringoli G. Neosporosis in water buffalo (Bubalus bubalis) in Southern Italy. Vet Parasitol 2000; 91(1-2): 15-21. http://dx.doi.org/10.1016/S0304-4017(00)00239-9. PMid:10889356.

Hamidinejat H, Seifi Abad Shapouri MR, Namavari MM, Shayan P, Kefayat M. Development of an Indirect ELISA using different fragments of recombinant Ncgra7 for detection of Neospora caninum infection in cattle and water buffalo. Iran J Parasitol 2015; 10(1): 69-77. PMid:25904948.

Hosmer DW, Lemeshow S. Applied Logistic Regression. John Wiley \& Sons, New York, 1989.

Huong LT, Ljungstrom BL, Uggla A, Björkman C. Prevalence of antibodies to Neospora caninum and Toxoplasma gondii in cattle and water buffaloes in Southern Vietnam. Vet Parasitol 1998; 75(1): 53-57. http://dx.doi. org/10.1016/S0304-4017(97)00178-7. PMid:9566094.

INSTITUTO BRASILEIRO DE GEOGRAFIA E ESTATÍSTICA IBGE. Efetivo rebanho bovideo brasileiro [online]. Rio de Janeiro: IBGE; 2016 [cited 2017 Dec 10]. Available from: https://cidades.ibge.gov.br/ brasil/pesquisa/18/16459

Kengradomkij C, Inpankaew T, Kamyingkird K, Wongpanit K, Wongnakphet S, Mitchell TJ, et al. Seroprevalence and risk factors associated with exposure of water buffalo (Bubalus bubalis) to Neospora caninum in Northeast Thailand. Vet Parasitol 2015; 207(1-2): 156-160. http://dx.doi.org/10.1016/j.vetpar.2014.10.034. PMid:25499824.

Konnai S, Mingala CN, Sato M, Abes NS, Venturina FA, Gutierrez CA, et al. A survey of abortifacient infectious agents in livestock in Luzon, the Philippines, with emphasis on the situation in a cattle herd with abortion problems. Acta Trop 2008; 105(3): 269-273. http://dx.doi. org/10.1016/j.actatropica.2007.12.004. PMid:18243149.

Konrad JL, Campero LM, Caspe GS, Brihuega B, Draghi G, Moore DP, et al. Detection of antibodies against Brucella abortus, Leptospira spp. and Apicomplexa protozoa in water buffaloes in the Northeast of Argentina. Trop Anim Health Prod 2013; 45(8): 1751-1756. http://dx.doi. org/10.1007/s11250-013-0427-y. PMid:23765549.

Konrad JL, Moore DP, Crudeli G, Caspe SG, Cano DB, Leunda MR, et al. Experimental inoculation of Neospora caninum in pregnant water buffalo. 
Vet Parasitol 2012; 187(1-2): 72-78. http://dx.doi.org/10.1016/j. vetpar.2011.12.030. PMid:22244534.

Meenakshi S, Sandhu KS, Ball MS, Kumar H, Sharma S, Sidhu PK, et al. Seroprevalence of Neospora caninum antibodies in cattle and water buffaloes in India. J Parasitol 2007; 93(6): 1374-1377. http://dx.doi.org/10.1645/ GE-1317.1. PMid:18314683.

Moore DP, Konrad JL, San Martino S, Reichel MP, Cano DB, Méndez $S$, et al. Neospora caninum serostatus is affected by age and speciesvariables in cohabiting water buffaloes and beef cattle. Vet Parasitol 2014; 203(3-4): 259-263. http://dx.doi.org/10.1016/j.vetpar.2014.04.011. PMid:24792747.

Nasir A, Ashraf M, Khan MS, Yaqub T, Javeed A, Avais M, et al. Seroprevalence of Neospora caninum in dairy buffaloes in Lahore District, Pakistan. J Parasitol 2011; 97(3): 541-543. http://dx.doi.org/10.1645/ GE-2687.1. PMid:21506867.

Neverauskas CE, Nasir A, Reichel MP. Prevalence and distribution of Neospora caninum in water buffalo (Bubalus bubalis) and cattle in the Northern territory of Australia. Parasitol Int 2015; 64(5): 392-396. http:// dx.doi.org/10.1016/j.parint.2015.05.009. PMid:25992666.

Portella LP, Cadore GC, Lima M, Sangioni LA, Fischer G, Vogel FSF. Antibodies against Neospora caninum, Sarcocystis spp. and Toxoplasma gondii detected in buffaloes from Rio Grande do Sul, Brazil. Pesq Vet Bras 2016; 36(10): 947-950. http://dx.doi.org/10.1590/s0100-736x2016001000005.

Reichel MP, McAllister MM, Nasir A, Moore DP. A review of Neospora caninum in water buffalo (Bubalus bubalis). Vet Parasitol 2015; 212(3-4): 75-79. http://dx.doi.org/10.1016/j.vetpar.2015.08.008. PMid:26298507.

Rodrigues AAR, Gennari SM, Paula VSO, Aguiar DM, Fujii TU, Starke-Buzetti W, et al. Serological responses to Neospora caninum in experimentally and naturally infected water buffaloes (Bubalis bubalis). Vet Parasitol 2005; 129(1-2): 21-24. http://dx.doi.org/10.1016/j. vetpar.2004.12.024. PMid:15817198.

Romero-Salas D, Alvarado-Esquivel C, Domínguez-Aguilar G, CruzRomero A, Ibarra-Priego N, Barrientos-Salcedo CB, et al. Seroepidemiology of infection with Neospora caninum, Leptospira, and bovine Herpesvirus Type 1 in water Buffaloes (Bubalus Bubalis) in Veracruz, Mexico. Eur J Microbiol Immunol (Bp) 2017; 7(4): 278-283. http://dx.doi. org/10.1556/1886.2017.00029. PMid:29403656.
Sengupta PP, Balumahendiran M, Raghavendra AG, Honnappa TG, Gajendragad MR, Prabhudas K. Prevalence of Neospora caninum antibodies in dairy cattle and water buffaloes and associated abortions in the plateau of Southern Peninsular India. Trop Anim Health Prod 2012; 45(1): $205-$ 210. http://dx.doi.org/10.1007/s11250-012-0192-3. PMid:22644733.

Silva JB, Nicolino RR, Fagundes GM, Bomjardim HA, Reis ASB, Lima DHS, et al. Serological survey of Neospora caninum and Toxoplasma gondii in cattle (Bos indicus) and water buffaloes (Bubalus bubalis) in ten provinces of Brazil. Comp Immunol Microbiol Infect Dis 2017; 52: 3035. http://dx.doi.org/10.1016/j.cimid.2017.05.005. PMid:28673459.

Silva JB, Santos PN, Castro GNS, Fonseca AH, Barbosa JD. Prevalence survey of selected bovine pathogens in water buffaloes in the north region of Brazil. J Parasitol Res 2014; 2014: 1-4. http://dx.doi. org/10.1155/2014/603484.

Silva SP, Mota RA, Faria EB, Fernandes EFTS, Neto OLS, Albuquerque PPF, et al. Anticorpos IgG anti-Neospora caninum e Toxoplasma gondii em búfalas (Bubalus bubalis) criadas no estado do Pará. Pesq Vet Bras 2010; 30(5): 443-446. http://dx.doi.org/10.1590/S0100-736X2010000500012.

Souza LM, Nascimento AA, Furuta PI, Basso LMS, Silveira DM, Costa AJ. Detecção de anticorpos anti-Neospora caninum e Toxoplasma gondii em soros de bubalinos (Bubalus bubalis) no estado de São Paulo, Brasil. Semina: Ciênc Agrár 2001; 22(1): 39-48. http://dx.doi.org/10.5433/16790359.2001v22n1p39.

Thrusfield M. Epidemiologia veterinária. São Paulo: Roca; 2004.

Vogel FSF, Arenhart S, Bauermann FV. Anticorpos anti-Neospora caninum em bovinos, ovinos e bubalinos no Estado do Rio Grande do Sul. Cienc Rural 2006; 36(6): 1948-1951. http://dx.doi.org/10.1590/ S0103-84782006000600048.

Williams D, Winden SV. Risk factors associated with high bulk milk antibody levels to common pathogens in UK dairies. Vet Rec 2014; 174(23): 580. http://dx.doi.org/10.1136/vr.102049. PMid:24789852.

Yu J, Xia Z, Liu Q, Liu J, Ding J, Zhang W. Seroepidemiology of Neospora caninum and Toxoplasma gondii in cattle and water buffaloes (Bubalus bubalis) in the People's Republic of China. Vet Parasitol 2007; 143(1): 79-85. http://dx.doi.org/10.1016/j.vetpar.2006.07.031. PMid:17010521. 